\title{
EVALUATION OF THE THERAPEUTIC EFFECTS OF MENTHA SPICATA ESSENTIAL OIL AT THE LIVER LEVEL IN DEVELOPING WISTAR RATS CO-EXPOSED TO LEAD AND MANGANESE
}

\author{
Mostapha Brahmi $^{*}$, Djallal Eddine Houari Adli' ${ }^{1}$, Miloud Slimani ${ }^{1}$, Wafaa Arabi ${ }^{1}$, Narimane \\ Taibi $^{1}$, Khaled Kahloula ${ }^{1}$ \\ Laboratory of Biotoxicology, Pharmacognosy and Biological recovery of plants, Department of Biology, \\ Faculty of Sciences, University of Dr MoulayTahar, Saida, Algeria \\ *brahmi.mustapha@gmail.com
}

https://doi.org/10.34302/crpjfst/2019.11.2.12

\begin{tabular}{|c|c|}
\hline Article history: & \multirow{4}{*}{$\begin{array}{l}\text { ABSTRACT } \\
\text { The objective of this study is to evaluate, on the one hand, the changes in } \\
\text { hepatotoxicity induced by lead and manganese according to a biochemical } \\
\text { and histological experimental approach in developing Wistar rats and, on } \\
\text { the other hand, to test the effectiveness of mint essential oil (Mentha } \\
\text { spicata) in restoring or not the harmful effects of the metals studied. by an } \\
\text { intraperitoneal injection of } 0,1 \mathrm{ml} \mathrm{HEM} / \mathrm{kg} / \text { day for a period of } 21 \text { days. } \\
\text { The characterization of this essential oil by gas chromatography coupled } \\
\text { with mass spectrometry indicates that the major components are: Carvone } \\
\text { ( } 42.2 \%) \text {, Menthone ( } 20.89 \% \text { ), Piperitenone (17.41\%) and Isomenthone } \\
(7.99 \%) \text {. The results of liver biochemical assays (aspartate } \\
\text { aminotransferase, alanine aminotransferase, alkaline phosphatase, albumin, } \\
\text { total cholesterol, and triglyceride) show a correction of values following } \\
\text { the administration of essential oil compared with those of co-exposed } \\
\text { animals. Analysis of the antioxidant status in the hepatocyte indicates that } \\
\text { this oil has restored the activity of the various antioxidant enzymes } \\
\text { (superoxide dismutase (SOD: } 0,87 \mathrm{U} / \mathrm{mg} \text { ), glutathione peroxidase (GPx: } \\
38,62 \mathrm{U} / \mathrm{mg} \text { ), and catalase(CAT: } 20,73 \mathrm{U} / \mathrm{mg} \text { )). In fact, the histological } \\
\text { study undertaken illustrated a clear improvement in liver tissue architecture } \\
\text { in rats intoxicated and treated with oil, which justifies the great importance } \\
\text { of Mentha spicata in traditional medicine and these therapeutic virtues. }\end{array}$} \\
\hline $\begin{array}{l}\text { Received: } \\
\text { 1 January } 2019 \\
\text { Accepted: } \\
\text { 29 May } 2019\end{array}$ & \\
\hline $\begin{array}{l}\text { Keywords: } \\
\text { GC-MS } \\
\text { Hepatotoxicity } \\
\text { Mentha spicata } \\
\text { Pb-Mn } \\
\text { Oxidative stress }\end{array}$ & \\
\hline & \\
\hline
\end{tabular}

\section{Introduction}

The heavy metals are a group of environmental chemicals which are both universal and non-biodegradable. Although the adverse effects resulting from exposure to them are well-known, their use and environmental concentration are increasing (Zhao et al, 2014). Numerous studies have revealed the toxicity of individual metals for living organisms (Basile et al, 2012). However, these metals do not only exist individually, but also combined in the environment (Smith et al, 2012)

In fact, lead is a non-essential element for the human body, due to its dispersal in the ambient air, as well as in many foods. Its toxicity is closely tied to its accumulation in certain tissues, and its interference with bioelements, whose role is essential for a number of physiological processes. It has numerous adverse effects, including neurological, 
behavioral, immunological, renal, hepatic, and in particular hematologic disorders (Annabi et al., 2007).

On the other hand, Manganese $(\mathrm{Mn})$ is a natural trace element its toxicity is multifactorial, because $\mathrm{Mn}$ directly interrupts the activation of enzymes, prevents competitive mineral absorption, changing calcium homeostasis and lowering the level of antioxidants available in the body (Adli, 2017).

Due to the pervasiveness of both metals, $\mathrm{Mn}$ and $\mathrm{Pb}$, reducing human exposure to toxic levels remains a global health challenge.

Moreover, aromatic plants produce active compounds (phytochemically having a pharmacological effect on living organisms) consisting in part of essential oils (Curutchet, 2014). Among these plants, Mentha spicata L., commonly called "naana" in Algerian medical systems, has many culinary and medicinal uses in the Maghreb. It is popularly consumed in the form of tea and added to several preparations as a flavor enhancer; dry or fresh spearmint leaf is added especially during tea brewing. Biliary disorders, menstrual pain, stomach aches, constipation, gingivitis, and waving are treated with decoction of spearmint leaves (Brahmi, 2012).

All these properties, typical of mint species, have been attributed to the combination of essential oil, essentially based on monoterpenoids (Brada, 2007), and polyphenolic derivatives (Dorman, 2003).

This study examined the impact of chronic co-exposure to lead acetate and manganese chloride at the hepatic level in Wistar rats during intrauterine life, lactation and after weaning, and then evaluated the effect of the essential oil of the plant Mentha spicata attenuated this hepatotoxicity in rats intoxicated by these two metals.

\section{Materials and methods}

2.1.Extraction and determination of the chemical composition of the essential oil by GC/MS

The leaves of spearmint (Mentha spicata) were harvested in Sidi Maàmar wilaya of Saida in the western Algerian highlands, then identified by taxonomic experts (Pr Hasnaoui department of biology, university Dr Moulay Tahar - saida). The sample was preserved, and the voucher specimen, coded P-200886, was deposited in the herbarium of the Biology Department of the Faculty of Sciences of the University of Saida, Algeria, for future reference.

The essential oil of mint (Mentha spicata) was extracted by hydrodistillation. The qualitative and quantitative analysis of this essential oil was then carried out by VARIAN CHROMPACK - CP 3900 gas chromatography by injecting $0.2 \mu 1$ extract. The carrier gas used is helium (He) with a flow rate of $0.3 \mathrm{ml} / \mathrm{min}$. The column used is a capillary column type VF5 (stationary phase nature: 5\% phenylpolysinoxane and $95 \%$ methyl), $30 \mathrm{~m}$ long and $0.25 \mathrm{~mm}$ inside diameter. The thickness of the stationary phase is $0.25 \mu \mathrm{m}$; the temperature of the initial injection column is programmed at $70^{\circ} \mathrm{C}$ for $2.50 \mathrm{~min}$, then rises in steps of $15^{\circ} \mathrm{C} / \mathrm{min}$ to $255^{\circ} \mathrm{C}$ for $20 \mathrm{~min}$; the detector used for this analysis is of the mass spectrometry type (Saturn 20200) with a temperature of $250^{\circ} \mathrm{C}$. The device is controlled by a menu computer, appropriate software for this type of analysis and a NIST database which allows the identification of the compounds.

\subsection{Distribution of lots}

The experiments were carried out on Wistar rats, weighing from 200 to $400 \mathrm{~g}$. The rats are grouped in cages at a rate of 2 females and one male. They are placed in a ventilated animal house, at a temperature of $21 \pm 1{ }^{\circ} \mathrm{C}$ with lighting artificiel which establishes a day/night cycle (day between 7 and $19 \mathrm{~h}$ ). On the first 
day of gestation, females are divided into two groups:

The intoxication of females begins on the first day of cohabitation with male rats which is represented by D0 and continues during the gestation period. Newborns are also exposed to $\mathrm{Pb}-\mathrm{Mn}$ until weaning (21 days after birth). Progeny is subject to the same experimental condition.

the distilled water. Tested offspring are subject to the same conditions as their mother.

Group T-HEM: 24 hours after weaning, animals receiving distilled water are treated with HEM mint essential oil $(0.1 \mathrm{ml} / \mathrm{kg})$ with one intraperitoneal injection per day for 21 days ( $\mathrm{n}=07$ male rats)

Group Pb-Mn-HEM: 24 hours after weaning, animals receiving $\mathrm{Pb}-\mathrm{Mn}$ are treated with HEM mint essential oil $(0.1 \mathrm{ml} / \mathrm{kg})$ with one intraperitoneal injection per day for 21 days ( $\mathrm{n}=07$ male rats) (Halder et al., 2011).

\subsection{Biochemical tests}

\subsubsection{Determination of blood lead and manganese levels}

After weaning and oil treatment, the animals are decapitated and the whole blood samples $(100 \mu \mathrm{l})$ are recovered in a $5 \mathrm{ml}$ haemolysis tube containing a volume of $100 \mu \mathrm{l}$ of $0.1 \%$ newt. After vortex agitation for 30 seconds, $600 \mu \mathrm{l}$ of $\mathrm{HNO}_{3}(1 \mathrm{M})$ is added to deproteinize. Vortex the contents of the hemolysis tube for 10 minutes at room temperature. After centrifugation for 10 minutes at $3000 \mathrm{rpm}$, the samples are transferred into wells to determine blood lead and manganese levels using an atomic absorption spectrophotometer (SHIMA DZU AA6200).

\subsubsection{Determination of liver parameters}

The serum samples were used to measure the activity of alanine aminotransferase (ALT), aspartate aminotransferase (AST) and alkaline phosphatase (ALP) according to the methods of Reitman and Frankle (1957). Determination of the concentrations of albumin, cholesterol and
Group $\mathrm{Pb}-\mathrm{Mn}$ : consisting of animals which receive orally lead acetate $\left(\mathrm{Pb}\left(\mathrm{C}_{2} \mathrm{H}_{3} \mathrm{O}_{2}\right)_{2}\right)$ at $0.2 \%$ and manganese chloride tetrahydrate $\left(\mathrm{MnCl}_{2} 4 \mathrm{H}_{2} \mathrm{O}\right)$ at $4.79 \mathrm{mg} / \mathrm{ml}$ in bidistilled water orally from the first day of gestation until weaning ( $\mathrm{n}=07$ male rats) (Kahloula et al.,2009 ; Molina et al., 2011)

Group $\mathrm{T}$ : is the control batch $(\mathrm{T})$ that receives

triglycerides by following the methods of Thomas (1992) and Fossati et Prencipe (1982) respectively.

\subsubsection{Measurement of antioxidant enzyme activity}

The rat liver was weighed and homogenized in a buffer solution containing $0.32 \mathrm{M}$ sucrose, $0.5 \mathrm{mM}$ EDTA, $10 \mathrm{mM}$ Tris$\mathrm{HCl}(\mathrm{pH} \mathrm{7.4)}$ in ice (1mg tissue $/ 4 \mathrm{ml}$ buffer solution) using a glass/glass homogenizer. The fabrics were maintained at $4^{\circ} \mathrm{C}$ during all dissection and homogenization procedures. The homogenate was centrifuged at $1000 \mathrm{xg}$ for 15 minutes at $4^{\circ} \mathrm{C}$. The supernatant thus obtained was centrifuged at $10000 \mathrm{xg}$ for 15 minutes at $4^{\circ} \mathrm{C}$. The pellet constitutes the mitochondrial fraction and supernatant is re-centrifuged at $10,000 \mathrm{~g} / 30$ minutes Both pellets thus obtained are solubilized in a buffer solution containing $0.32 \mathrm{M}$ sucrose, $0.5 \mathrm{mM}$ EDTA, $10 \mathrm{mM}$ Tris$\mathrm{HCl}$ and $0.02 \%$ digitonin ( $\mathrm{pH} 7.4$ ), digitonin is added to release all imprisoned mitochondria in the synaptosomes and centrifuged a second time at $10000 \times \mathrm{g}$ for $15 \mathrm{mn}$ at $4^{\circ} \mathrm{C}$, the pellet thus obtained constitutes the fraction of the total mitochondria which will be solubilized in a solution containing sucrose $(0.32 \mathrm{M}$ at $\mathrm{pH}$ 7.4) (Rotruck ,1973).

Super oxidize dismutase (SOD) (EC 1.15.1.1) was analyzed on supernatant using the technique of Kakkar (1984); this method is based on inhibition of formation of adenine nicotinamide dinucleotide, phenazine methosulfate and formazan amino tetra zoliumblue. Activities and levels of antioxidants at the brain level such as catalase (CAT), glutathione peroxidase (GPx) were 
analyzed by the (Sinha, 1972), (Rotruck ,1973) methods respectively.

\subsection{Histological study}

Samples of liver spleen were collected and fixed in $10 \%$ buffered neutral formalin solution, dehydrated in gradual ethanol (70$100 \%)$, cleared in xylene, and embedded in paraffin. Paraffin sections ( $5 \mu \mathrm{m}$ thick) were prepared, routinely stained with hematoxylin and eosin (H\&E) dyes (Suvarna et al., 2013), and then examined microscopically.

\subsection{Expression and statistical analysis of results}

The results are expressed as the mean (M) of the individual values, assigned from the standard error to the mean (SEM). The comparison of several means is carried out by an analysis of variance (one wayAnova) with the intoxication factor ( $\mathrm{Pb}-\mathrm{Mn}, \mathrm{T})$. Repeatedmeasure Anova were used for time factor analysis. A probability $\mathrm{p}<0.05$ is considered significative. Statistical analyses were performed using Sigma Stat software (SPSS Inc., Chicago, IL, USA).

\section{Results and discussions}

\subsection{Performance and chemical composition of HEM}

The hydro-distillation of the plant matter Mentha spicata allowed to obtain a yield of $0.83 \%$. this disagrees with the work of (Priscilla et al.,2010) which reported a value of $(0.23 \pm 0.04 \%)$ and with those of (Lucchesi et al.,2004), (0.60 $\pm 0.06-\%)$.This difference in yield can be attributed to several factors, mainly origin, species, harvest period, drying time and essential oil extraction technique (Karousou et al., 2005) ; moreover (Marotti et al.,1994) have shown that low yields can be associated with a series of factors such as genotype, plant development stages and environmental conditions that occur in semiarid regions.

The analysis of the essential oil of Mentha spicata by gas chromatography identified 12 major compounds listed in Table 1 by order of elution. Twelve components representing the sum of the percentages of the components obtained were identified $(98.51 \%)$, of which $96.71 \%$ are monoterpene ketones, $1.75 \%$ are monoterpene hydrocarbons, $0.05 \%$ are oxides . The major components of this oil are: Carvone (42.2\%), Menthone (20.89\%), Piperitenone (17.41\%) and Isomenthone(7.99\%). The results obtained for the various works show that this oil is essentially made of Carvone (de Sousa Barros et al., 2015).

Table 1.Concentration in $\%$ and retention time of the different compounds obtained by gas chromatographic analysis of the essential oil of M.spicata.

\begin{tabular}{|c|c|c|}
\hline Compounds & Retention time (min) & Concentration (\%) \\
\hline$\alpha$-pinene & 11.200 & 0.40 \\
\hline Sabinene & 12.080 & 0.56 \\
\hline$\beta$-pinene & 12.440 & 0.70 \\
\hline Octane-3-one & 12.820 & 1.15 \\
\hline Paracymen & 13.600 & 0.09 \\
\hline 1.8 cineole & 14.110 & 0.05 \\
\hline Menthone & 18.213 & 20.89 \\
\hline Isomenthone & 18.710 & 7.99 \\
\hline Pulegone & 21.460 & 0.05 \\
\hline Carvone & 21.480 & 42.2 \\
\hline
\end{tabular}




\begin{tabular}{|c|c|c|}
\hline Piperiton & 22.010 & 7.02 \\
\hline Piperitenone & 23.150 & 17.41 \\
\hline Total of identifiers & $\mathbf{9 8 , 5 1}$ \\
\hline
\end{tabular}

Table 2. Effect of the essential oil of the M.spicata plant on the various biochemical parameters in rats intoxicated by $\mathrm{Pb}-\mathrm{Mn}$ compared to control rats.

\begin{tabular}{|c|c|c|c|c|}
\hline Parameters & Pb-Mn & Pb-Mn+HE & Control & HEM \\
\hline Lead levels $(\mu \mathrm{g} / \mathrm{dl})$ & $34,1 \pm 0,81 *$ & $21,18 \pm 4,01 *$ & $0,27 \pm 0,028$ & $0,25 \pm 0,022$ \\
\hline $\begin{array}{l}\text { Manganese content } \\
(\mu \mathrm{g} / \mathrm{dl})\end{array}$ & $2,38 \pm 0,02 * *$ & $1,21 \pm 0,1 * *$ & $1,03 \pm 0,1$ & $0,99 \pm 0,04$ \\
\hline Glucose $(\mathrm{g} / \mathrm{l})$ & $1,80 \pm 0,02 *$ & $1,42 \pm 0,04 *$ & $0,91 \pm 0,06$ & $1,13 \pm 0,01$ \\
\hline $\begin{array}{l}\text { alanine } \\
\text { aminotransferase } \\
\text { ALT (IU/l) }\end{array}$ & $42,10 \pm 0,87 *$ & $26 \pm 0,21 *$ & $21,08 \pm 0,8$ & $20,57 \pm 0,3$ \\
\hline $\begin{array}{l}\text { aspartate } \\
\text { aminotransferase } \\
\text { AST (IU/l) }\end{array}$ & $36,79 \pm 0,4 *$ & $13,31 \pm 0,4 *$ & $11,37 \pm 0,3$ & $10,98 \pm 0,1$ \\
\hline $\begin{array}{l}\text { Alkaline phosphatase } \\
(\mathrm{U} / \mathrm{l})\end{array}$ & $59,82 \pm 0,30^{*}$ & $46,66 \pm 1,9 *$ & $43,39 \pm 0,10$ & $42,86 \pm 0,14$ \\
\hline Albumin (g/dl) & $3,05 \pm 0,2 *$ & $4,78 \pm 0,14^{*}$ & $5,03 \pm 0,04$ & $5,15 \pm 0,07$ \\
\hline total cholesterol (g/l) & $2,66 \pm 0,02 * *$ & $1,29 \pm 0,15 * *$ & $1,09 \pm 0,03$ & $1,05 \pm 0,02$ \\
\hline Triglycerides (g /l ) & $0,89 \pm 0,02 * *$ & $0,68 \pm 0,07 * *$ & $0,63 \pm 0,04$ & $0,59 \pm 0,05$ \\
\hline
\end{tabular}

Values are reported as \pm SEM on average $(* *: p<0.01, *: p<0.05)$.

\subsection{Results of biochemical parameters}

The results obtained from blood lead and manganese assays using atomic absorption spectrophotometry (AAS) are in the order of $2.38 \pm 0.02 \mu \mathrm{g} / \mathrm{dl}$ for rats intoxicated by $\mathrm{Pb}-\mathrm{Mn}$ (Table 02). These levels are significantly decreased $(p<0.01)$ following administration of the plant extract $(1.21 \pm 0.1)$ in the batch of previously intoxicated rats (Mn-HEM).

The level of $\mathrm{Pb}$ and $\mathrm{Mn}$ in the blood are effective biomarkers and representative of their exposure. Physiological blood lead is zero because lead is not necessary for the life of living things. After digestive absorption, lead passes into the blood where it is distributed in red blood cells, in a non-diffusible form before settling in tissues or being eliminated in urine. Blood is therefore the crossroads of all lead pathways in the body (Pezerat, 2006). The use of atomic spectrophotometry allowed us to record lead levels in the order of $34.1 \pm 0.81$ $\mu \mathrm{g} / \mathrm{dl}$ in rats exposed to $\mathrm{Pb}$ acetate. (Goullé et al .,2012) Recent experimental studies have determined lead concentrations in intoxicated rats to range from 31.8 to $58.7 \mu \mathrm{g} / \mathrm{dl}$ (Grizzo,2008).

The highest amount of $\mathrm{Mn}$ in the blood is contained in erythrocytes (about 66\%), with a half-life of 37 days. (Lee et Kim, 2011). The Mn level found in our study is significantly elevated in intoxicated rats compared to control rats. however, studies have shown that during pregnancy, blood Mn concentrations increase over the three semesters and Mn penetrates the placenta by active transport (Krachler et al.,1999).the increase in Mn levels during pregnancy may also be related to the acceleration of erythropoiesis, intestinal absorption or the tissue that mobilizes $\mathrm{Mn}$ (Tholin et al., 1995).

Exposure to $\mathrm{Pb}-\mathrm{Mn}$ resulted in hyperglycemia in poisoned rats compared to control rats. These results are consistent with those of Kasdallah et al. (2005) who confirm that exposure to Mn produces a stressful effect that results in hyperglycemia under the action 
of stress hormones. Moreover, Kasdallah et al. (2005) ; Huang et al. (1989) report that chronic administration of lead and manganese during the development period leads to a dysfunction of energy metabolism this increase in blood glucose concentration is probably the result of glycogenolysis, neoglucogenesis which is confirmed by liver damage to cover the body's energy needs.

Analysis of liver function markers indicates that at serum levels ALT and AST activity are significantly higher in intoxicated rats $(\mathrm{Pb}-\mathrm{Mn})$ compared to control rats $(\mathrm{p}<0.05)$.treatment with M.spicata essential oil showed a significant decrease in transaminase (ALT, AST) activity compared to $\mathrm{Pb}-\mathrm{Mn}$ intoxicated rats. These two enzymes are located in the cytosol and the increase in their serum concentration is due to their possible release from the cytoplasm following destruction of the plasma membrane and stress on the cell (Shyamala et al., 2003). Several studies have reported that lead induces high hepatotoxicity and causes changes in the architecture of the hepatocyte, leading to a sharp increase in transaminases (Dini et al., 1999). The work of (Fordahl et al.,2012) indicates that wide exposure to $\mathrm{Mn}$ has an effect on liver metabolites, mainly causing disturbances in lipid metabolism and thus excessive formation of oleic acid, hydroxy-butyric acid and ketone bodies, the latter being in surplus in the blood will be eliminated in the urine, adding that alterations in liver metabolites have been correlated with tissue increase in manganese. The liver participates in many phases of lipid metabolism, esterification and elimination of cholesterol, only free cholesterol determination and serum esterification has been widely used for the study of liver disease (Awde, 2014). However, the results presented in our study showed hypercholesterolemia and hypertriglyceridemia in poisoned rats compared to control rats. Our results are similar to the work of Hanan et al. (2012) ; Sharma et al. (2013) who found an increase in triglyceride and cholesterol levels in the blood after administration of lead acetate.

In addition, the relationship between lead acetate exposure and cholesterol levels suggests a possible alteration in lipid metabolism (Moussa et Bashandy, 2008). In contrast, Zwingmann et al. (2003) have shown that Mn can lead to biliary tract closure and inhibition of bile acid transfer to the gallbladder and its accumulation in the liver leading to hypercholesterolemia

The work of Fordahl et al. (2012) indicates that wide exposure to $\mathrm{Mn}$ has an effect on liver metabolites, mainly causing disturbances in lipid metabolism and thus excessive formation of oleic acid, hydroxybutyric acid and ketone bodies.

\subsection{Activity of enzymes of oxidative status in the liver}

Endogenous antioxidant enzymes are responsible for neutralizing the free radical and preventing its action responsible for tissue damage. Oxidative stress results from an imbalance between the production of reactive oxygen species (ROS) and antioxidant defenses, which in turn causes a series of events deregulating cellular functions. Antioxidant enzymes, such as SOD, CAT and GPX form a team in solidarity with the defense against ROS (Bandyopadhyay et al., 1999).

After $\mathrm{Pb}-\mathrm{Mn}$ exposure, SOD, GPx and CAT activity are significantly lower $(\mathrm{p}<0.001$, $\mathrm{p}<0.05)$ respectively in intoxicated rats compared to hepatic control rats. After 21 days of treatment with HEM, a marked improvement in the activity of these enzymes was observed in treated rats compared to intoxicated rats (Table 03). It has been shown that the accumulation of lead in the various liver cell compartments produces oxidative damage by strengthening the peroxidation of membrane lipids and the oxidation of proteins, a deleterious process produced solely by free radicals (Villeda-Hernandez et al., 2001).

Several studies suggest that exposure to $\mathrm{Mn}$ induces a variety of cellular changes due to 
increased oxidative stress, and inadequate the link between oxidative stress and energy systems metabolisms and antioxidants mitochondrial dysfunction due to exposure to (Roth et Garrick, 2003). Studies have shown this metal (Mn) (Milatovic et al., 2009).

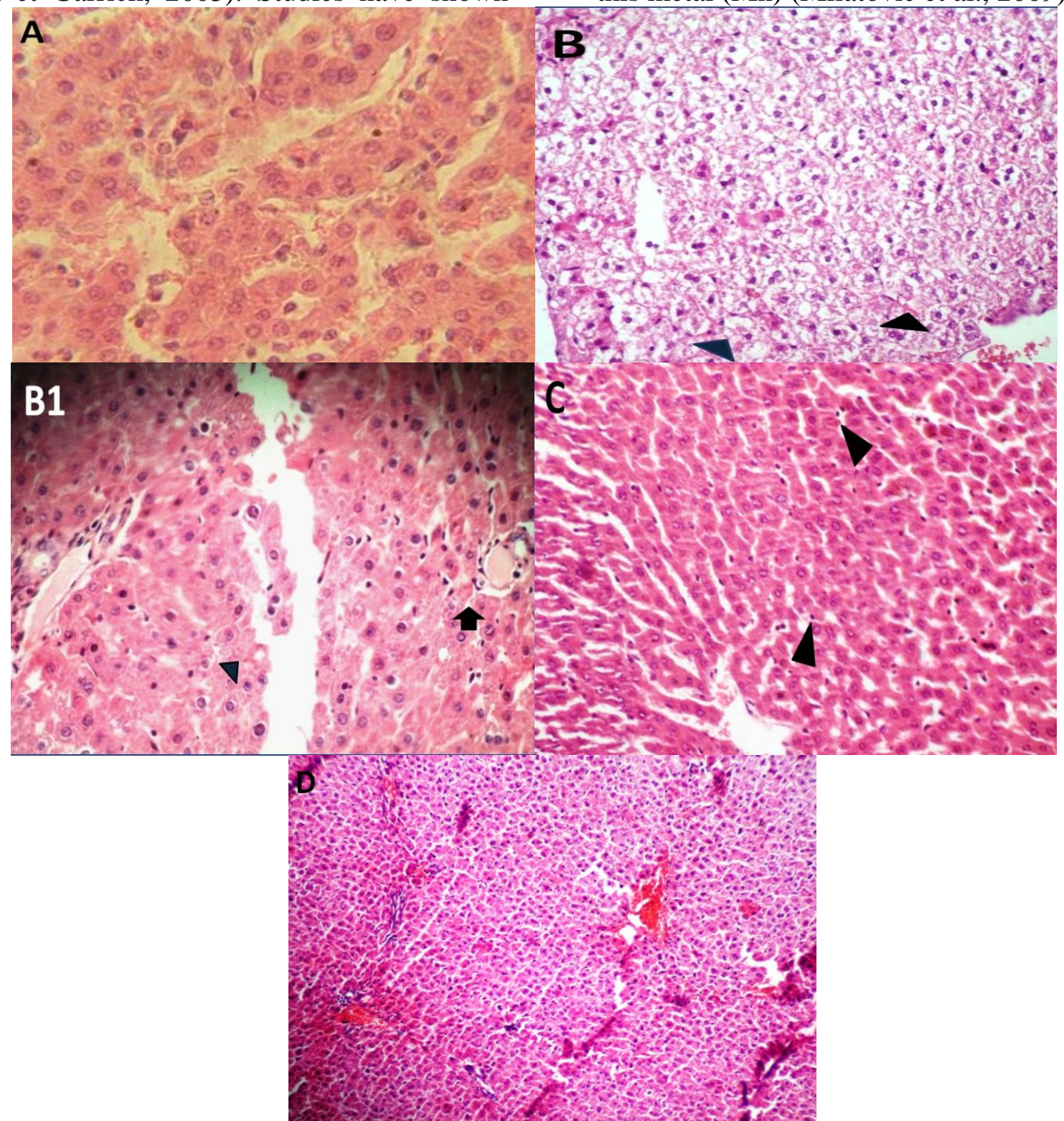

Figure 1: Optical microscopy of hepatic tissue stained with hematoxylin and eosin $G:(x 40)$. (A)G :( x100) in sections of the liver of control rats appeared with normal architecture (B, B1) Rats exposed to lead and manganese revealed a necrosis microfocus (blue arrow), portal inflammation (black arrow) (C) of rats intoxicated with $\mathrm{Pb}-\mathrm{Mn}$ and treated with $\mathrm{HEM}$ illustrates moderate inflammation (black arrow). (D) normal liver sections of rats treated with HEM.

Arrows indicate necrosis microfocus Portal inflammation 
Table 3. Liver antioxidant enzyme activity (SOD, GPx, CAT) in control rats, Pb-Mn and $\mathrm{Pb}-\mathrm{Mn}-\mathrm{HEM}$.

\begin{tabular}{|l|l|l|l|c|}
\hline \multicolumn{1}{|c|}{$\begin{array}{c}\text { Concentration in the } \\
\text { liver }\end{array}$} & \multicolumn{1}{|c|}{ Pb-Mn } & Pb-Mn-HEM & \multicolumn{1}{|c|}{ control } & HEM \\
\hline SOD(U/mg of protein) & $0,22 \pm 0,14 * * *$ & $0,87 \pm 0,33 * * *$ & $1,03 \pm 0,26 * * *$ & $1,10 \pm 0,06$ \\
\hline GPx(U/mg of protein) & $25,31 \pm 0,31 *$ & $38,62 \pm 0,08 *$ & $43,41 \pm 0,12 *$ & $40,75 \pm 0,62$ \\
\hline CAT (U/mg of protein) & $11,38 \pm 0,15 *$ & $20,73 \pm 0,97 *$ & $25,27 \pm 0,22 *$ & $26,08 \pm 0,03$ \\
\hline
\end{tabular}

Values are reported as \pm SEM on average $(* *: p<0.01, *: \mathrm{p}<0.05)$.

\subsection{The effect of lead and manganese on the structural architecture of the liver}

Histological sections of the liver of rats intoxicated by lead and manganese show necrosis and the hepatic parenchyma site of swelling, ballooning of the hepatocytes and lipid vacuoles within the hepatocytes producing steatosis foci, a necrosis microfocus (Figure 01.B, B1) compared to the liver of the control rats. These results are similar with studies by Jarrar et al. (2012) suggesting that subchronic exposure to lead causes liver damage in rats. The appearance of inflammatory cells in liver tissue due to sub-chronic exposure to lead may suggest that lead may interact with proteins and enzymes in interstitial liver tissue interfering with the antioxidant defense mechanism and lead to reactive oxygen species (ROS) which in turn may mimic an inflammatory response (Johar et al ., 2004). In addition, the liver is the critical organ for regulating Mn homeostasis in the body. In the same way, Mn toxicity is rare and occurs mainly in the liver, probably because of the primary role this organ plays in eliminating Mn from the blood through biliary excretion (Crossgrove et Zheng, 2004), consumption of water contaminated with $\mathrm{Mn}$ causes liver overflow which can lead to liver damage (Peili et al., 2011).Indeed several studies have reported that $\mathrm{Mn}$ induces a histopathological alteration by a necrosis of the liver and appoptoseperiportal (Rahelié et al., 2006) which could compromise the detoxifying function of the liver to know how to eliminate manganese (Zhang et al., 2003). Mint is usually used in the treatment of biliary system disorders, liver problems, irritable bowel syndrome and inflammatory bowel disease (Bouchra et al.,2003). The effects of mint are related to its effect on bile flow and liver function (Taylor,1984 ). On the other hand it is observed that blood glucose levels are decreased in rats treated with Mentha spicata EHM compared to intoxicated rats. The administration of mint essential oil to rats exposed to $\mathrm{Pb}-\mathrm{Mn}$ resulted in a decrease in blood glucose levels, it has been shown that mint extract performs hypoglycemic activity due to the presence of major components such as menthol and menthone (Khodadust et al., 2015) In addition, the results of Bayani et al. (2017) indicated that aqueous extract of $M$. spicata leaves possesses hypoglycemic, hypocholesterolemic and antioxidant properties in diabetic rats. In parallel, a significant decrease in transaminases (ALT,AST) was also observed following the administration of M.spicata HEM which indicates regulation of liver function biomarkers.Consistent with the results of this study, Rajesh et al. (2013) reported that elevated serum ALT biochemical markers in rats with hepatic lesions were decreased with the addition of ethanolic extract of mint leaves (Mentha arvensis) at $400 \mathrm{mg} / \mathrm{kg}$ . Barbalho et al. (2011) studied the effects of administration of mint juice twice daily for 30 days on certain biochemical parameters in humans, the results showed a $41.5 \%$ reduction in blood sugar, $58.5 \%$ in triacylglycerides, $66.9 \%$ in total cholesterol, $52.3 \%$ in LDL indices, $70 \%$ in AST levels, $74.5 \%$ in ALT levels.

Treatment with HEM in intoxicated rats showed an improvement in cholesterol values, triglycerides and oxidative status enzymes (SOD,CAT, GPx). These results are similar 
with the work of Al-Fartosi et al. (2014) showed that phenolic compounds of Mentha longifolia and Mentha spicata leaf extract in diabetic rats significantly reduced serum cholesterol levels compared to untreated groups. The cholesterol-lowering effect of mint could be due to the menthol and menthone content which has the property of reducing the activity of a liver enzyme HMG CoA reductase (a primordial enzyme in the synthesis of cholesterol in the liver) and simultaneously reducing cholesterol levels. (Poltowicz et Wesyk, 2005). Mentha arvensis leaves have the highest phenol and flavonoid content which explains why it has the greatest antioxidant property and reduces cholesterol levels (Vishwakarma et al., 2014).

It has also been observed that the administration of HEM M.spicata protective action of liver tissue that could be explained by the chelating and antioxidant effect of phenolic components contained in HEM, which significantly reduces free radicals generated by intoxication that causes cell damage in liver tissue. (Muruganathan et Srinivasan, 2016) Our results are in harmony with Vinothkumar et al., (2013), which report that carvone reduces oxidative stress by improving enzymatic antioxidant activity in rats poisoned by $1,2-$ dimethylhydrazine. However, other authors have illustrated that treatment with carvone restored the activities of serum ALT and AST and ALP levels in rats treated with streptozotocin, indicating the maintenance of liver cell function and structure (Muruganathan et Srinivasan, 2016). Another study indicated that in vivo administration of peppermint alcohol extract reduced the adverse effects of CCl4 on liver function (Khodadust et al., 2015).

\section{Conclusions}

Exposure of developing wistar rats to $\mathrm{Pb}$ $\mathrm{Mn}$ revealed hepatotoxic effects resulting in significant alteration of liver bio markers and the antiradical system represented by different enzymes. Treatment with $M$. spicata HEM clearly demonstrated effective hypoglycemia, hypolipidemia and remarkable liver protection in rats previously intoxicated with $\mathrm{Pb}-\mathrm{Mn}$.

\section{References}

Adli, D.E.H., Kahloula, K., Slimani, M., Brahmi, M., Benreguieg, M. (2017). Effets prophylactiques de l'huile essentielle de Syzygium aromaticum chez les rats wistar en développement coexposés au plomb et au manganèse. Phytothérapie. 1-7 DOI 10.1007/s10298-017-1130-3

de Sousa Barros, Alexandre \& Morais, Selene \& Augusto Travassos Ferreira, Pablito \& Gusmão Pinto Vieira, Ícaro \& Craveiro, Afranio \& Fontenelle, Raquel \& Eire Silva Alencar de Menezes, Jane \& Walber Ferreira da Silva, Francisco \& Araújo de Sousa, Halisson. (2015). Chemical composition and functional properties of essential oils from Mentha species. Industrial Crops and Products. 76, 557564. 10.1016/j.indcrop.2015.07.004.

Annabi, B. A., Nehdi, A., Hajjaji, N., Gharbi, N., El-Fazâa, S. (2007). Antioxidant enzymes activities and bilirubin level in adult rat treated with lead. Comptes Rendus Biologies.330(8):581-8.

Awde, S. (2014). Relations entre protéolyse hépatique et qualités technologiques et sensorielles $\mathrm{du}$ foie gras de canard (Doctoral dissertation). Toulouse - France.

Bandyopadhyay, U., Das, D., \& Banerjee, R.K. (1999). Reactive oxygen species: oxidative damage and pathogenesis. Current science, 658-666.

Barbalho, S.M., Machado, F.M.V.F., Oshiiwa, M., Abreu, M., Guiger, E.L., Tomazela, P., and Goulart, R.A. (2011). Investigation of the effects of peppermint (Mentha piperita) on the biochemical and anthropometric profile of university students. Ciencia Tecnologia de Alimentos Campinas. 31(3), 584-588.

Basile, A., Sorbo, S., Conte, B., Cobianchi, R,C., Trinchella, F., Capasso, C. and Carginale,V. (2012). Toxicity, accumulation, and removal of heavy 
metals by three aquatic macrophytes, Int. J. Phytoremediat. (14), 374-387.

Bouchra, C., Achouri, M., Idrissi Hassani, L.M., \& Hmamouchi, M. (2003). Chemical composition and antifungal activity of essential oils of seven Moroccan Labiatae against Botrytis cinerea. Journal of Ethnopharmacolgy.89, 165-169.

Brada, M., Bezzina, M., Marlier, M., Carlier, A., Lognay, G. (2007). Variabilité de la composition chimique des huiles essentielles de Mentha rotundifolia du Nord de l'Algérie. Biotechnologie. Agronomie. Société et Environnement. 11 (1), 3-7.

Brahmi, F., Madani, K., Dahmoune, F., Rahmani, T., Bousbaa, K., Oukmanou, S., Chibane, M. (2012). Optimization of solvent extraction of antioxidants (phenolic compounds) from Algerian mint (Mentha spicata L.). Pharmacognosy Communications. 2 (4), 72-86. DOI: 10.5530/pc.2012.4.10

Crossgrove, J., and Zheng, W. (2004). Manganese toxicity upon over exposure. NMR Biomed. 17: 544-553.

Curutchet, A., Dellacassa, E., Ringuelet, J.A., Chaves, A.R., Vĩna, S.Z. (2014). Nutritional and sensory quality during refrigerated storage of fresh-cut mints (Mentha piperita and M. spicata). Food Chemistry. 143, 231-238.

Dini, A., Giudetti, A., Ruzittu, M., Gnoni, G., and Zara, V. (1999). Citrate Carrier and lipogenic enzyme activities in lead nitrateinduced proliferative and Apoptotic phase in rat liver. Biochemistry and Molecular Biology International. 47, 607-14.

Dorman, H.J.D., Kosar, M., Kahlos, K., Holm, Y., Hiltunen, R. (2003). Antioxidant properties and composition of aqueous extracts from Mentha species, hybrids, varieties, and cultivars. Journal of Agricultural and Food Chemistry, 51, 4563-4569.

Fordahl, S., Cooney, P., Qiu ,Y., Xie, G., Jia, W., and Erikson, K.M. (2012).Waterborne manganese exposure alters plasma, brain, and liver metabolites accompanied by changes in stereotypic behaviors. Neurotoxicology and Teratology. 34(1):2736.

Fossati, P., Prencipe, L. (1982). Serum triglycerides determined colorimetrically with an enzyme that produces hydrogen peroxide. Clinical Chemistry.28, 20772080.

Goullé, J.P., Saussereau, E., Lacroix, C., and Guerbet, M.(2012). Traité de toxicologie médico-judiciaire .Re : Chapitre 24; Métaux ., 733-756.

Grizzo, L.T., and Cordellini, S.(2008). perinatal lead exposure affects nitric oxide and cyclooxygenase pathways in aorta of weaned rats. Toxicological Sciences.103,207-214.

Halder, S., Mehta, A.K., Kar, R., Mustafa, M., Mediratta, P.K., Sharma, K.K.(2011). Clove oil reverses learning and memory deficits in scopolamine-treated mice. Planta Medica.77,830-4.

Hanan, A., and Riham, M.(2012). Effect of lead toxicity on cytogenisity, biochemical constituents and tissue residue with protective role of activated charcoal and casein in male rats, Australian Journal of Basic And Applied Sciences.;6(7), 497-509.

Huang, C.C., Chu, N.S., Lu, C.S., Wang, J.D., Tsai, J.L., Tzeng, J.L., Wolters, E.C., and Calne, D.B.(1989). Chronic manganese intoxication. Jama Neurology. 46: 1104 1106. PMID: 2803069

Jarrar, Bashir. M., and Noory, T.T. (2012).Histological and histochemical alterations in the liver induced by lead chronic toxicity. Saudi Journal of Biological Sciences. (19), 203-210.

Johar, D., Roth, J.C., Bay, G.H., Walker, J.N., and Kroczak, T.J., Los, M. (2004). Inflammatory response, reactive oxygen species, programmed (necrotic-like and apoptotic) cell death and cancer. Roczniki Akademia Medyczna w Biatymstoku. 49, 31-39. 
Kahloula, K., Slimani, M., Dubois, M., Bonnet, J. (2009). D-cycloserineenhances spatial learning performances of rats chronically exposed to lead during the developmental period. African Journal of Neurological Sciences, 28:67-77.

Kakkar, P., Das, B., Viswanathan, P.N. (1984). A modified spectrophotometric assay of superoxide dismutase. Indian Journal of Biochemistry and Biophysics, 21,130-2.

Karousou, R., Koureas, D.N., Kokkini, S. (2005). Essential oil composition is related to the natural habitats: Corido Thymus capitatus and Satureja thymbra in Natura 2000. Phytochemistry, 66, 2668-73.

Kasdallah, A.G., Mornagui, B., Gharbi, N., Machghoul, S., El-Faza, S.(2005). Metabolic and endocrine effects of water and/or food deprivation in rats. Comptes Rendus Biologies.328,463-470.

Khalid, G., Al-Fartosi., Haider, Radi., Eman, A., Al-Rekabi. (2014). Lipid Profile of Diabetic Male Rats Treated with Phenolic Compounds of Leaves Extracts from Mentha longifolia and Mentha spicata. International Journal of Pharmacy, Biology and Medical Sciences.Vol.3. No. 2.

Khodadust, M.R., Samadi F., Ganji, F., Jafari, A.Y., and Asadi, G.H. (2015).Effects of peppermint (Mentha piperita L.) alcoholic extract on carbon tetrachloride-induced hepatotoxicity in broiler chickens under heat stress condition. Poultry Science Journal, 3 (1): 1-16.

Krachler, M. (1999). Trace element transfer from the mother to the newborn ,investigations on triplets of colostrum, maternal and umbilical cord sera. European Journal of Clinical Nutrition.53,486-494.

Lee, B.K., Kim,Y. (2008). Relationship between blood manganese and blood pressure in the Korean general population according to knhanes Environmental Research, 111,797-803.

Lucchesi, M.E., Chemat, F., Smadja, J. (2004). Solvent free microwave extraction of essential oil from aromatic herbs: Comparison with conventional hydrodistillation. Journal of Chromatography A, 1043, 323-327.

Mahsan, B., Mahmood, A.H., Ashkan, J.J. (2017). Study of Hypoglycemic,Hypocholesterolemic and Antioxidant Activities of Iranian Mentha Spicata Leaves Aqueous Extract in Diabetic Rats. Iranian Journal of Pharmaceutical Research, 16 (Special Issue), 75-82.

Marotti, M., Piccaglia, R., Giovanelli, E., Deans, S.G., Eaglesham, E. (1994). Effects of planting time and mineral fertilization on peppermint (Mentha piperita L.) essential oil composition and its biological activity. Flavour and Fragrance Journal, 9 (3),125129.

Milatovic, D., Zaja, M. S., Gupta, R.C., Yu, Y., Aschner, M. (2009). Oxidative damage and neurodegeneration in manganese-induced neurotoxicity. Toxicology and Applied Pharmacology, 240, 219-225.

Molina, R.M., Phattanarudee, S., Kim, J., Thompson, K., Wessling-Resnick, M., Maher, T.J., Brain, J.D. (2011). Ingestion of $\mathrm{Mn}$ and $\mathrm{Pb}$ by rats during and after pregnancy alters iron metabolism and behavior in offspring. Neurotoxicology. 32, 413-22.

Moussa, S.A., Bashandy, S.A. (2008). Biophysical and biochemical changes in the blood of rats exposed to lead toxicity. Romanian Journal of Biophysics,18, 123133.

Peili,H., Chunxia, C., Hui,W., Guojun, L., Haiming, J., Ying, $H$. ,Na,L.,Yang,X.,Qiuhong,Y.,Yuting,L.,Peng wen,W.,Zhixiong,Shi.,Zhi,w. S. (2011). Manganese effects in the liver following subacute or subchronic manganese chloride exposure in rats. Ecotoxicology and Environmental Safety. (74) 615-622.

Pezerat, H. (2006). Additif au mémoire d'avril sur le projet d'une nouvelle rédaction.$L a$ Revue de Médecine Interne. 5, 1-4. 
Poltowicz, K., Wesyk, S. (2005). Effect of garlic oil supplementation in laying hen nutrition on the level of egg yolk cholesterol. Materialy XVII Miedzynaraodowego symposium Drobiarskiego, Polska, 137-138.

Priscilla, P. A., Natália, M., Sandra, F.R.S.(2010). -journal food bioprocess technologyvol. 3, no. 4,1-12

Rahelié, D.M., Kujundzié, Z., Romié et al. (2006). Serum concentration of zinc. Copper. Manganese and magnésieum in patients with liver cirrhosis. Collegium Antropologicum., 30 (3), 523-28

Rajesh, K., Vishwanath, A.H., Shivakmar, S.I., Joshi, V., Kurnool, A.N. (2013). Hepatoprotective and antioxidant activity of ethanol extract of Mentha arvensis leaves against carbon tetrachloride induced hepatic damage in rats. international journal of pharmacy research and technology. 5, 426-430.

Reitman, S., Frankle, S. (1957). Coloremetric method for determination of serum transaminase activity. American Journal of Clinical Pathology. 28, 56-68.

Roth, J. A., Garrick, M. D. (2003). Iron interactions and other biological reactions mediating the physiological and toxic actions of manganese. Biochemical pharmacology, 66(1), 1-13. PMID: 12818360

Rotruck, J.T., Pope, A.L., Ganther, H.E. (1973). Selenium: biochemical role as a component of glutathione peroxidase, Science, 179, 588-90.

Sharma, S., Shrivastava, S., Shukla, S. (2013). Reversal of lead-induced toxicity due to the effect of antioxidants. Journal of Environmental Pathology, Toxicology, and Oncology, 32, 177-187.

Shyamala, M.P., Venukumar, M.R., Latha, M.S. (2003). Antioxidant potential of the syzygium aromaticum (Gaertn.) LINN (cloves) in rats fed with high fat diet.
Indian Journal of Pharmacology, 35, 99103.

Sinha, A.K. (1972). Colorimetric assay of catalase. Analytical Biochemistry 47:38994.

Smith,S., Gancarz,D., Rofe,F., Kempson,I.M., Weber, J and Juhasz, A. L.(2012). Antagonistic effects of cadmium on lead accumulation in pregnant and non-pregnant mice, Journal of Hazardous Materials, (199) 453-456.

Suvarna, S.K., Layton, C., Bancroft, J.D. (2013). Bancroft's theory and practice of histological techniques. 7 th Ed. England: Churchill Livingstone. Elsevier.

Taylor, B. ((1984). The mechanism of the inhibitory action of menthol on gut smooth muscle. British Journal of Surgery.71, 902-908.

Tholin, K. (1995). Changes in blood manganese levels during pregnancy in iron supplemented and non supplemented women. J, Trace Elem,Med,Biol (9), 13-17

Thomas, C., Thomas, L. (1992). Labor diagnostik v on Erkrankung en der Nier en und ableitendenHar (hrsg)Dans: Thomas L, 6 éd. Philadelphi, Labor und Diagnose.

Udaiyar, M., Subramani, S. (2016). Beneficial effect of carvone, a dietary Monoterpene ameliorates hyperglycemia by regulating the key enzymes activities of carbohydrate metabolism in streptozotocin-induced diabetic rats. Biomedicine \&Pharmacotherapy. 84, 1558-1567.

Villeda-Hernandez, J., Barroso-Moguel, R., Mendez-Armenta, M., Nava-Ruiz, C., Huerta-Romero, R., Rios, C. (2001). Enhanced brain regional lipid peroxidation in developing rats exposed to low level lead acetate. Brain research bulletin.55(2), 247251

Vishwakarma, S., Chauhan, K., Jeba, R. C., Khushbu, S. (2014). Comparative study of qualitative phytochemical screening and antioxidant activity of Mentha arvensis, Elletaria cardamomum and Allium 
porrum. Indo American Journal of Pharmaceutical Research.4, 2538-2556.

Zhang, S., Zhou, Z., Fu, J.(2003). Effect of manganese chloride exposure on liver and brain mitochondria function in rats. Environmental Research 93(2), 149-157.

Zhao, Q., Wang,W., Cao, Y.,Chen,Y., Ren,A., Ge,Y., Yu,Z., Wan ,S., $\mathrm{Hu}, \mathrm{A}$ and Bo,Q.(2014). Potential health risks of heavy metals in cultivated topsoil and grain including correlations with human primary liver, lung and gastric cancer,in Anhui province, Eastern China, Science of the Total Environment, 470, 340-347.

Zwingmann, C., Leibfritz, D., Hazell, A. (2003). Role of Manganese in hepatic encephalopathy. Netherlands: Kluwer Academic Press. 